Arq. Bras. Med. Vet. Zootec., v.70, n.1, p.254-262, 2018

\title{
Meat quality of chicken of different crossings in alternative system
}

[Qualidade da carne de frangos de diferentes cruzamentos em sistema alternativo]

F.L. Cruz, A.A. Silva, I.F.M. Machado, L.C. Vieira, C. Esteves, E.J. Fassani, P.B. Faria

Universidade Federal de Lavras - Lavras, MG

\begin{abstract}
The purpose was to evaluate the effects of gender and of different genotypes of chickens on the physicochemical parameters and centesimal composition, related to the quality of meat. The design was completely randomized arranged in $5 \times 2$ factorial scheme, five genotypes (Índio Gigante - IG; New Hampshire - NHS; Gigante Negra de Jersey - GNJ; poultry from the crossing between the IG and NHS breeds - IG x NHS; and between the IG and GNJ breeds - IG x GNJ) and two genders, with five repetitions and each one represented by three poultry, totaling 150 animals, slaughtered at 105 days. The parameters evaluated on the breast and thigh were: centesimal composition (moisture, ether extract - EE, protein and ash), ultimate $\mathrm{pH}$, color ( $\mathrm{L}^{*}$ - luminosity, $\mathrm{a}^{*}$ - redness, $\mathrm{b}^{*}$-yellowness, $\mathrm{C}^{*}$ - chroma index and $\mathrm{h}^{*}$ - hue angle), weight loss by cooking (WLC) and shear force (SF). The IG genotype had the highest average of ultimate $\mathrm{pH}$ of the breast (6.03). The NHS and IG x NHS genotypes showed, respectively, higher average of $\mathrm{L} *(58.93)$ and $\mathrm{a} *(1.92)$ of the breast. The IG, IG x NHS and IG x GNJ showed the highest values of $b^{*}$ of the breast $(12.53,13.37$ and 12.69 , respectively). The IG poultry showed high average of SF of the breast and thigh (4.79 and 5.01kgf, respectively). The IG x NHS and IG x GNJ genotypes showed the lowest ultimate $\mathrm{pH}$ values of the thigh (6.13 and 6.02, respectively). The IG $\mathrm{x}$ GNJ genotype showed a high average of $b^{*}$ of the thigh (14.94) and the NHS had a high average of WCL (24.65\%). The females showed higher averages of EE on the breast and ash on the thigh (1.03 and $1.11 \%$, respectively). The IG x NHS and IG x GNJ poultry showed higher averages of EE of the breast (1.21 and $1.38 \%$, respectively). The poultry of IG breed and those from the crossing with NHS and GNJ presented meat quality characteristics more desirable by the consumer in relation to physicochemical parameters and centesimal composition, while genders showed no influence on these aspects.
\end{abstract}

Keywords: shear force, índio gigante, luminosity, protein, color

\section{RESUMO}

Objetivou-se avaliar os efeitos de sexo e de diferentes genótipos de frangos sobre os parâmetros físicoquímicos e a composição centesimal, relacionados à qualidade da carne. O delineamento foi inteiramente ao acaso, disposto em esquema fatorial (5x2), sendo cinco genótipos (Índio Gigante - IG; New Hampshire - NHS; Gigante Negra de Jersey - GNJ; aves oriundas do cruzamento entre as raças IG e NHS - IG x NHS; e entre as raças IG e GNJ - IG x GNJ) e dois sexos, com cinco repetições, sendo cada uma representada por três aves, totalizando 150 animais, abatidos aos 105 dias. Os parâmetros avaliados no peito e na coxa foram: composição centesimal (umidade, extrato etéreo - EE, proteína e cinzas), $p H$ final, cor ( $L^{*}$ - luminosidade, $a^{*}$ - teor de vermelho, $b^{*}$ - teor de amarelo, $C^{*}$ - índice de croma e $h^{*}$ - angulo de tonalidade), perda de peso por cozimento (PPC) e força de cisalhamento (FC). $O$ genótipo IG apresentou a maior média de pH final do peito $(6,03)$. Os genótipos NHS e IG x NHS apresentaram, respectivamente, médias elevadas de $L^{*}(58,93)$ e $a^{*}(1,92)$ do peito. Os IG, IG x NHS e IG $x$ GNJ apresentaram os maiores valores de $b^{*}$ do peito $(12,53,13,37$ e 12,69 , respectivamente). As aves IG apresentaram médias elevadas de FC do peito e da coxa (4,79 e 5,01Kgf, respectivamente). Os genótipos IG x NHS e IG x GNJ apresentaram os menores valores de pH final da coxa (6,13 e 6,02,

Recebido em 30 de agosto de 2016

Aceito em 23 de fevereiro de 2017

E-mail: fabiolourescruz@gmail.com 
respectivamente). O genótipo IG x GNJ apresentou média elevada de $b^{*}$ da coxa $(14,94)$, e o NHS média elevada de PPC (24,65\%). As fêmeas apresentaram maiores médias de EE no peito e de cinzas na coxa (1,03 e 1,11\%, respectivamente). As aves IG x NHS e IG x GNJ apresentaram maiores médias de EE do peito (1,21 e 1,38\%, respectivamente). As aves da raça IG e as oriundas de seu cruzamento com NHS e GNJ apresentaram características de qualidade de carne mais desejáveis pelo consumidor em relação aos parâmetros físico-químicos e de composição centesimal, enquanto o sexo não revelou influência sobre esses aspectos.

Palavras-chave: força de cisalhamento, índio gigante, luminosidade, proteína, cor

\section{INTRODUCTION}

The current demand of modern consumers for more natural products has promoted significant evolution of the alternative system for the production of free-ranging type chicken, which presents meat with more wholesome aspects for the consumption, such as lower saturated fat and cholesterol, in addition to the desirable particular organoleptic properties such as more marked flavor and firmer texture (Faria et al., 2009; Zanusso e Dionello, 2003).

Nevertheless, to make the activity profitable, it is necessary to seek an increased understanding of the factors which directly affect the parameters of meat quality such as genetic makeup and gender of birds (Souza et al., 2012). The choice of the gender can bring about differences in the meat quality due to the differences of sexual maturity and growth potential (Santos et al. 2005), while the use of strains with different growth potency can cause differences in the meat quality parameters like texture and color (Faria et al., 2009; Souza et al., 2012), which are highly important mainly to the free range type chicken market. In search of improvements in the main meat quality attributes, breeders of free-ranging chickens have conducted crosses among these different breeds adapted to the alternative production system.

So, birds of the New Hampshire breed which present good characteristics for meat production and early sexual maturity (around four to five months) can be utilized in several crosses since they gave rise to a great deal of present commercial broiler hybrids as well as the birds of the Gigante Negra de Jersey breed which present large size and aptitude for meat production (Albino et al., 2014). On the other hand, a recent breed which has grown among the farmers is the birds of the Índio Gigante breed, which in spite of ornamental, are utilized for meat production due to its larger size, despite their being less precocious, reaching the sexual maturity around seven months (ABCIG, 2016). However, there are no recent studies reporting the result of the crosses of these breeds about the meat quality aspects.

It was intended through this study to evaluate the physicochemical and centesimal composition parameters related to the meat quality of chickens of different breeds, crosses and gender raised in alternative system.

\section{MATERIAL AND METHODS}

The experiment was conducted in the Poultry Farming Sector of the Animal Science Department of the Federal University of Lavras (Universidade Federal de Lavras (UFLA)), in Lavras - MG, Brazil. A total of 150 birds, vaccinated previously against Marek, Fowlpox and Newcastle disease, being 75 males and 75 females, all adapted to the alternative production system.

The experimental design was completely randomized (CRD) arranged in factorial scheme (5x2), being five genotypes (purebred Índio Gigante - IG, purebred New Hampshire - NHS, purebred Gigante Negra de Jersey - GNJ, F1 generation resulting from the cross between roosters of the Índio Gigante breed and hens of the New Hampshire breed - IG x NHS, F1 generation resulting from the cross between roosters of the Índio Gigante breed and hens of the Gigante Negra de Jersey breed- IG x GNJ) and two genders (male and female), amounting to 10 treatments. Each treatment consisted of five replications where each replication or experimental unit was made up of three birds previously identified, amounting to 15 birds per treatment. The diet for the free-ranging type broilers was composed of three dietary formulations (Table 1) according to the raising phase, which was established according to the 
age of the bird in days. The birds of the different genotypes were reared in three phases: starter (1 to 30 days), reared in breezeblock sheds, with feed and water ad libitum, with no access to the grazing area, receiving heating with gas hoods till 14 days of age and artificial lighting 24 hours a day throughout that phase; in the growing phase (31 to 55 days) and final phase (56 to 105 days), the birds were raised in experimental area of free-ranging raising with access to the grazing area and feed and water ad libitum and in each experimental unit of $90 \mathrm{~m}^{2}$ of area, 30 birds of the same genotype were housed, being 15 of each gender, obtaining a density of one bird for each three $\mathrm{m}^{2}$ of area, meeting the Circular Letter DOI/DIPOA number $007 / 99$ of $19 / 05 / 1999$ (Brazil, 1999).

At 105 days of age, the birds were maintained at fasting for 8 hours and slaughtered by cervical dislocation followed by bleeding with cutting of the jugular veins and carotid arteries, respecting the humanitarian slaughter method. Afterwards, the scalding and plucking step was performed, followed by the butchering and packing of the carcasses in an individual manner in plastic bags duly identified, the pre-cooling step not being carried out. Next, the packed carcasses were taken to refrigeration at the temperature of $5 \pm 2^{\circ} \mathrm{C}$ for 24 hours.

After that period, samples of the skin-free breast and thigh were collected for the conduction of the physicochemical analyses (final $\mathrm{pH}$, color, weight loss by cooking and shear force) and centesimal composition (moisture, protein, ether extract and ash) of the meat. On the breast, the physicochemical and centesimal composition analyses were carried out on the pectoralis major muscle and on the thigh, the set of muscles present in the cranial portion of the femur, encompassing the fibularis longus, tibial cranial, flexor digitorum longus, extensor digitorum longus and gastrocnemius muscles.

Table 1. Compositions and values calculated from the experimental diets for free-ranging type broilers according to the raising phase and age range in days

\begin{tabular}{|c|c|c|c|}
\hline Ingredient (kg) & Starter (1 to 30$)$ & Growing (31 to 55 ) & Final (56 to 105$)$ \\
\hline Corn & 57.91 & 63.69 & 68.54 \\
\hline Soybean meal & 31.48 & 25.94 & 24.03 \\
\hline Wheat meal & 6.81 & 7.01 & 4.23 \\
\hline Bicalcium phosphate & 1.59 & 1.36 & 1.31 \\
\hline Limestone & 1.35 & 1.26 & 1.18 \\
\hline Common salt & 0.38 & 0.35 & 0.33 \\
\hline Mineral Premix ${ }^{1}$ & 0.10 & 0.10 & 0.10 \\
\hline Vitamin premix ${ }^{2}$ & 0.10 & 0.10 & 0.10 \\
\hline DL-Methionine 99\% & 0.20 & 0.14 & 0.13 \\
\hline L-Lysine 78\% & 0.03 & & \\
\hline Choline chloride $60 \%$ & 0.05 & 0.05 & 0.05 \\
\hline Total $(\mathrm{kg})$ & 100 & 100 & 100 \\
\hline \multicolumn{4}{|l|}{ Calculated values } \\
\hline Crude protein $(\%)$ & 20.00 & 18.00 & 17.00 \\
\hline $\mathrm{ME}^{3}(\mathrm{kcal} / \mathrm{kg})$ & 2800 & 2870 & 2940 \\
\hline Calcium (\%) & 1.00 & 0.90 & 0.85 \\
\hline Available phosphorus (\%) & 0.42 & 0.37 & 0.35 \\
\hline Sodium (\%) & 0.17 & 0.16 & 0.15 \\
\hline $\operatorname{dig} \mathrm{M}+\mathrm{C}^{4}(\%)$ & 0.74 & 0.64 & 0.61 \\
\hline Digestible Lysine (\%) & 0.96 & 0.81 & 0.76 \\
\hline Digestible tryptophan $(\%)$ & 0.22 & 0.19 & 0.18 \\
\hline Crude fiber $(\%)$ & 3.32 & 3.14 & 2.86 \\
\hline
\end{tabular}

${ }^{1}$ Mineral premix: Manganese 75,000mg, zinc 70,000mg, iron 50,000mg, copper 8,500mg, iodine 1,500mg, cobalt 200mg. ${ }^{2}$ Vitamin premix: Vitamin A 7,000,000IU, vitamin $\mathrm{D}_{3} 2,100,000 \mathrm{IU}$, vitamin E 50,000mg, vitamin $\mathrm{K}_{3} 2,000 \mathrm{mg}$, vitamin $\mathrm{B}_{1}$ 2,000mg, vitamin $B_{2} 4,000 \mathrm{mg}$, vitamin $B_{6} 3,000 \mathrm{mg}$, Vitamin $B_{12} 3000 \mathrm{mg}$, niacin $39,800 \mathrm{mg}$, pantothenic acid $15,620 \mathrm{mg}$, folic acid 1,000mg, selenium $200 \mathrm{mg}$, biotin $100 \mathrm{mg}$, antioxidant $100,000 \mathrm{mg}$. ${ }^{3} \mathrm{ME}$ : metabolizable energy; ${ }^{4} \mathrm{dig} \mathrm{M}+\mathrm{C}$.: methionine plus digestible cystine. 
The $\mathrm{pH}$ reading was accomplished with a digital $\mathrm{pH}$ meter of the Hanna Instruments mark, HI 99163 model. The color was determined according to the CIEL*a*b* color system where: $\mathrm{L}^{*}$ - luminosity, $\mathrm{a}^{*}$ - redness and $\mathrm{b}^{*}$ - yellowness, these measures being determined through the use of the colorimeter of the Minolta Chroma mark Meter-200b, with a D65/10 ${ }^{\circ}$ illuminant, calibrated to standard white tile. The reading of each cut in the experimental unit being obtained on the muscular portion 24 hours after slaughter. From the values of $a^{*} e^{*}$, the values of chrome $\left(\mathrm{C}^{*}\right)$ and hue angle $\left(\mathrm{h}^{*}\right)$ according to the methodology of Ramos and Gomide (2007) were obtained.

For determination of the weight loss by cooking (WLC), the breast and thigh samples were weighed and involved in aluminum foil and submitted to cooking on a electric plate at the temperature of $150^{\circ} \mathrm{C}$, remaining till they reached the internal temperature of $72^{\circ} \mathrm{C}$. After cooking, the samples were cooled in a refrigerator for 12 hours and then weighed. For calculation of the values of WLC, the values being expressed in percentage were utilized as means of the differences among the weights before and after the cooking of both the cuts and of each replication.

The samples cooled for determination of the WLC were cut into pieces with dimensions of $2.0 \mathrm{x} 1.0 \mathrm{x} 10 \mathrm{~cm}$ in the lengthwise of the muscle fibers for the doing of the shear force analyses (SF) according to the methodology of Fronning and Uijttenboogarte (1988). Afterwards, the samples were sectioned crosswise to the muscle fibers, utilizing a texturometer of the Extralab Mark, TA.XT Plus model, the results being expressed in kgf.

The determinations of centesimal composition (moisture, protein, ether extract and ash) were performed from the chest and thigh muscles (skin-free) according to AOAC methodology (1995).

The data were analyzed with the support of the statistical program SISVAR $\AA$. The statistical analysis of the variables for the factors genetic group, gender and/or interaction among them, was conducted through the Tukey averages test $(\alpha=0.05)$, since all the variables are parametric. All procedures described were approved by the
Ethics Committee on Animal Use (CEUA) of the Federal University of Lavras (protocol number 017/14).

\section{RESULTS AND DISCUSSION}

The Statistical analysis revealed no interaction $(\mathrm{P}>0.05)$ between the genotypes and gender for the physicochemical parameters of the breast meat. There were differences among the genetic groups $(\mathrm{P}<0.01)$ for the values of final $\mathrm{pH}$ of the breast and the Indio Gigante birds (IG) showed the highest mean (Table 2). This result agrees with those found by Faria et al. (2009); Sirri et al. (2011); Souza et al. (2012); Sarica et al. (2014) who observed higher $\mathrm{pH}$ means in slow growing strains.

Genetic improvement of broilers for a higher rate of growth and production of muscle mass generally provides an increase in the amount of glycolytic muscle fibers that modifies the predominant energy metabolism, resulting into a greater extent of postmortem glycolysis and production of lactic acid in the muscle (Castellini et al., 2002). Thus, birds with a lower degree of improvement for meat production and earliness, such as IG birds, tend to present a greater number of oxidative fibers in the musculature and with this, there is a reduction in the rate of fall and in the values of final $\mathrm{pH}$.

In the breast cut, the New Hampshire birds (NHS) presented the highest values of luminosity (L*) $(\mathrm{P}<0.01)$, being, nevertheless, similar to the means obtained by the genotypes GNJ and IG $\mathrm{x}$ GNJ (Table 2). In general, the modification in this parameter is related to the increased bright on the surface of the cut, which can be from the effect of lower $\mathrm{pH}$ values and denaturation of the myoglobin pigments where the exudation of liquid promotes a greater dispersion of light (Gomide et al., 2013). For the redness (a*) of the breast, the IG $x$ NHS and IG birds presented similar means, revealing that crossing presented higher mean $(\mathrm{P}<0.01)$ relative to the other genetic groups (Table 2). Faria et al. (2009); Sirri et al. (2011); Souza et al. (2011); Sarica et al. (2014) also found differences in the values of $a^{*}$ among strains due to the growth potential. According to Gordon and Charles (2002), the differences in the red contents among strains are due to the red content of myoglobin of the muscle. 
Table 2. Physicochemical parameters of the meat of the breast and thigh of broilers of different genetic groups raised in alternative system

\begin{tabular}{|c|c|c|c|c|c|c|c|c|c|c|c|}
\hline \multirow{2}{*}{ Variables } & \multicolumn{5}{|c|}{ Genotype (G) } & \multicolumn{2}{|c|}{ Gender (GD) } & \multicolumn{3}{|c|}{$\mathrm{P}^{1}$} & \multirow{2}{*}{$\mathrm{CV}^{2}(\%)$} \\
\hline & NHS & GNJ & IG & IGXNHS & IGXGNJ & Male & Female & G & GD & GXGD & \\
\hline \multicolumn{12}{|c|}{ Breast } \\
\hline $\mathrm{PH}$ & $5.83 \mathrm{~B}$ & $5.84 \mathrm{~B}$ & $6.03 \mathrm{~A}$ & $5.87 \mathrm{~B}$ & $5.75 \mathrm{C}$ & 5.86 & 5.87 & 0.001 & 0.408 & 0.542 & 0.98 \\
\hline $\mathrm{L}^{*}$ & $58.93^{\mathrm{a}}$ & $56.25 \mathrm{AB}$ & $54.21 \mathrm{~B}$ & $52.36 \mathrm{~B}$ & $55.02 \mathrm{AB}$ & 56.04 & 54.67 & 0.001 & 0.156 & 0.521 & 6.05 \\
\hline $\mathrm{A}^{*}$ & $-1.06 \mathrm{~B}$ & $-0.33 \mathrm{~B}$ & $0.75 \mathrm{AB}$ & $1.92 \mathrm{~A}$ & $-0.03 \mathrm{~B}$ & -0.07 & 0.57 & 0.001 & 0.123 & 0.117 & 579.99 \\
\hline $\mathrm{B}^{*}$ & $9.91 \mathrm{~B}$ & $11.02 \mathrm{AB}$ & $12.53 \mathrm{~A}$ & $13.37 \mathrm{~A}$ & $12.69 \mathrm{~A}$ & 11.77 & 12.04 & 0.002 & 0.636 & 0.684 & 16.95 \\
\hline $\mathrm{C}^{*}$ & $10.02 \mathrm{C}$ & $11.07 \mathrm{BC}$ & $12.57 \mathrm{ABC}$ & $13.76 \mathrm{~A}$ & $13.75 \mathrm{AB}$ & 11.82 & 12.24 & 0.002 & 0.476 & 0.582 & 17.15 \\
\hline $\mathrm{H}^{*}$ & $96.97^{\mathrm{a}}$ & $92.56 \mathrm{AB}$ & $87.21 \mathrm{BC}$ & $82.57 \mathrm{C}$ & $90.20 \mathrm{ABC}$ & 91.28 & 88.53 & 0.001 & 0.117 & 0.228 & 6.76 \\
\hline WLC (\%) & 21.63 & 17.00 & 19.53 & 17.96 & 16.63 & 19.68 & 17.43 & 0.060 & 0.060 & 0.540 & 22.62 \\
\hline SF (KGF) & $2.86 \mathrm{~B}$ & $2.96 \mathrm{~B}$ & $4.79 \mathrm{~A}$ & $3.39 \mathrm{~B}$ & $2.54 \mathrm{~B}$ & 3.40 & 3.22 & 0.001 & 0.557 & 0.975 & 32.48 \\
\hline \multicolumn{12}{|c|}{ Thigh } \\
\hline $\mathrm{PH}$ & $6.29^{a}$ & $6.36 \mathrm{~A}$ & $6.29 \mathrm{~A}$ & $6.13 \mathrm{~B}$ & $6.02 \mathrm{~B}$ & 6.22 & 6.22 & 0.001 & 0.917 & 0.045 & 1.53 \\
\hline $\mathrm{L}^{*}$ & 49.08 & 49.39 & 47.92 & 48.97 & 49.03 & 48.52 & 49.24 & 0.532 & 0.210 & 0.038 & 4.07 \\
\hline $\mathrm{A}^{*}$ & 5.46 & 5.40 & 5.98 & 5.28 & 6.17 & 5.79 & 5.53 & 0.481 & 0.482 & 0.125 & 23.36 \\
\hline $\mathrm{B}^{*}$ & $13.59 \mathrm{BC}$ & $13.73 \mathrm{AB}$ & $12.35 \mathrm{C}$ & $13.56 \mathrm{BC}$ & $14.94 \mathrm{~A}$ & 13.44 & 13.83 & 0.001 & 0.188 & 0.123 & 7.57 \\
\hline $\mathrm{C}^{*}$ & $14.67 \mathrm{AB}$ & $14.77 \mathrm{AB}$ & $13.73 \mathrm{~B}$ & $14.73 \mathrm{AB}$ & $16.18 \mathrm{~A}$ & 14.65 & 14.98 & 0.002 & 0.349 & 0.125 & 8.27 \\
\hline $\mathrm{H}^{*}$ & 68.22 & 68.74 & 64.18 & 69.13 & 67.53 & 66.74 & 68.39 & 0.146 & 0.216 & 0.249 & 6.91 \\
\hline WLC (\%) & $24.65^{\mathrm{a}}$ & $23.79 \mathrm{AB}$ & $20.79 \mathrm{AB}$ & $21.93 \mathrm{AB}$ & $20.15 B$ & 22.13 & 22.41 & 0.011 & 0.754 & 0.777 & 14.20 \\
\hline SF (KGF) & $3.79 \mathrm{~B}$ & $4.00 \mathrm{AB}$ & $5.01 \mathrm{~A}$ & $4.04 \mathrm{AB}$ & $3.70 \mathrm{~B}$ & 4.17 & 4.05 & 0.007 & 0.627 & 0.352 & 20.21 \\
\hline
\end{tabular}

${ }^{1}$ Tukey test $(\alpha=0.05)$; ${ }^{2}$ Coefficient of variation; namely: NHS - New Hampshire; GNJ - Gigante Negra de Jersey; RIR - Rhode Island Red; IG Índio Gigante; IG x NHS - F1 generation of the crossing between birds of the Índio Gigante and New Hampshire breeds; IG x GNJ - F1 generation of the crossing between birds of the Índio Gigante and Gigante Negra de Jersey breeds; L* - luminosity, $\mathrm{a}^{*}$ - redness, $\mathrm{b}^{*}$ yellowness, $\mathrm{C}^{*}$ - saturation index, $\mathrm{h}^{*}$ - hue angle, WLC - weight loss by cooking and, SF - shear force; means followed by small letters (ab) denote difference between gender; means followed by capital letters $(\mathrm{AB})$ indicate difference among genotypes.

The IG, IG x NHS and IG x GNJ birds presented the highest values $(\mathrm{P}<0.01)$ of yellowness $\left(\mathrm{b}^{*}\right)$ of the breast in relation to the NHS, but they were similar to the GNJ (Table 2), which denotes greater capacity of deposition of carotenoid pigments in this cut for these genetic groups. According to Faria et al. (2009) the greater the consumption of grasses the more yellow the meat will be due to the increased incorporation in the muscle of the carotenoid pigments present in plants. In general, birds with poorer growth potentials showed higher yellow contents in the breast meat (Grashorn, 2006; Faria et al., 2009; Mikulski et al., 2011; Souza et al., 2011), this result can be related to a greater grazing habit.

The NHS birds presented higher values $(\mathrm{P}<0.01)$ for tone angle $\left(\mathrm{h}^{*}\right)$ of the color of the breast, meat, which did not differ, however, from the genetic groups GNJ and IG x GNJ (Table 2). The values of $\mathrm{h}^{*}$ indicate that the predominant color of the breast meat, despite the difference between the genetic groups, was yellow, according to the color scale in the CieL*a*b * System (yellow -70 to $100^{\circ}$ ). The IG $x$ NHS birds showed a higher mean $(\mathrm{P}<0.05)$ for color saturation index $(\mathrm{C} *)$, being similar to the genetic groups IG and IG $x$ GNJ (Table 2), indicating that these animals present a higher intensity of the yellow color.
There was no effect of the genotype and gender $(\mathrm{P}>0.05)$ for the variable weight loss by cooking (WLC) of the breast (Table 2) in spite reports in the literature of difference for that parameter as result of the different growth potentials of the birds (Fanatico et al., 2007; Sirri et al., 2011).

For the values of shear force (SF) of the breast, there was an effect of the genetic groups $(\mathrm{P}<0.01)$, the IG birds showed a higher mean in relation to the others (Table 2). This behavior may be related to the lower content of ether extract (intramuscular fat) in the meat of the $\mathrm{CH}$ birds (Table 4), which, even being similar to the means found by the NHS and GNJ genotypes, influenced this variable. According to Alves et al. (2005) there is a negative correlation between intramuscular fat content and shear force values, so that the lower the intramuscular fat content, the greater the force required to shear the meat and, consequently, the lower its softness will be. These results agree with those of Coelho et al. (2007); Souza et al. (2011, 2012) who observed higher values of HR of the breast for the strains of lower growth potentials.

Another factor which may be related to meat texture is the content of conjunctive tissue of meat, mainly as far as the collagen fiber present 
in the interior of the muscles is concerned. In that way, as the animal grows old, there is an increase of the number of thermostable cross-links of the muscle collagens, contributing thus to an increase in the meat toughness. In this process, the genetic differences among the breeds can directly influence collagen content in the muscle as well as in the process of cross-links formation (Alves et al., 2005).

In general, gender did not influence the physicochemical parameters related to meat quality (Table 2). These results agree with those found by Souza et al. (2011) and Sarica et al. (2014) in which no influence of gender over the parameters of final $\mathrm{pH}$, cooking loss, texture and color was observed. That behavior indicates that the birds in this study presented characteristics of similar muscle tissue composition and that at the age which they were slaughtered, they had not reached sexual maturity where greater influences over these aspects are found (Souza et al., 2012).

There was no effect of the genetic groups and gender $(\mathrm{P}>0.05)$ over the redness $\left(\mathrm{a}^{*}\right)$ of the thigh meat (Table 2). These results contrast with those found in the literature which showed differences among genotypes for the values of $\mathrm{a}^{*}$ (Faria et al., 2009; Souza et al., 2012), highest means being observed for birds with higher growth rates.

For the yellowness $\left(\mathrm{b}^{*}\right)$ of the thigh, increased mean $(\mathrm{P}<0.01)$ was found for IG $\mathrm{x}$ GNJ birds, this being similar to the GNJ (Table 2). Differences among values of $b^{*}$ of the thigh were reported by Fanatico et al. (2007) and Souza et al. (2011) where the slow- growing strains presented higher means. For the values of the hue angle $\left(\mathrm{h}^{*}\right)$ of the thigh, there was no difference among the genetic groups $(\mathrm{P}>0.05)$ which showed predominant orange color according to the CieL*a*b* System scale (25 to $\left.70^{\circ}\right)$. The IG $x$ GNJ birds presented greater mean $(\mathrm{P}<0.01)$ of saturation index of the color chroma $\left(\mathrm{C}^{*}\right)$ of the thigh as compared with the $\mathrm{IG}$, but it was similar to the means obtained by NHS, GNJ and IG x NHS (Table 2).

For the weight loss by cooking (WLC) of the thigh, the NHS birds presented greater value
$(\mathrm{P}<0.01)$, this being similar to that found for the GNJ, IG and IG $x$ NHS genetic groups. However, the IG $x$ GNJ birds showed a lower mean $(\mathrm{P}<0.01)$ of WLC and, therefore, a greater yield (Table 2). Fanatico et al. (2007); Faria et al. (2009); Sarsenbek et al. (2013) also observed differences among strains for values of WLC of the thigh, that behavior being ascribed to the means of final $\mathrm{pH}$, growth potential and amount of muscle tissue.

The IG birds presented greatest value of shear force $(\mathrm{SF})$ in the thigh $(\mathrm{P}<0.01)$ relative to the NHS and IG $x$ GNJ genotypes, with means similar to those obtained by GNJ and IG x NHS (Table 2). These higher values of SF are obtained in meat with firmer texture. Souza et al. (2012) found differences in the values of shear force of the thigh for different strains and ascribed that behavior in relation to the differences of precocity among them, since the velocity of reduction of the collagen solubility is related to the development rate and physiological maturity. However, for the IG birds, reduced value of ether extract was also found (Table 4) which is related to a decreased amount of intramuscular fat and also can influence the aspects of meat tenderness (Alves et al., 2005).

The results of the centesimal composition of the cuts breast and thigh of the chickens of the different genetic groups and gender are presented in Table 3; where interaction among those factors was found only for the variable thigh moisture $(\mathrm{P}<0.01)$.

The fact that the IG genotype presented the lowest mean $(\mathrm{P}<0.01)$ of ether extract in the breast and thigh (Table 3 ), being, nevertheless, similar to the means obtained by the NHS and GNJ genotypes, indicate that the birds of those groups tend to reach sexual maturity at a more advanced age, since the accumulation or deposition of fat in the carcass occurs later, there being, therefore, little amount of intramuscular fat when compared with the other genotypes evaluated at the same age. Those results agree with the ones of Sirri et al. (2011); Sarsenbek et al. (2013) who observed lower ether extract contents of the thigh of slow-growing birds and of later precocity. 
Table 3. Centesimal composition of the thigh and breast meat of broilers raised in an alternative system

\begin{tabular}{|c|c|c|c|c|c|c|c|c|c|c|c|}
\hline \multirow{2}{*}{ Variables } & \multicolumn{5}{|c|}{ Genotype (G) } & \multicolumn{2}{|c|}{ Gender (GD) } & \multicolumn{3}{|c|}{$\mathrm{P}^{1}$} & \multirow{2}{*}{$\mathrm{CV}^{2}(\%)$} \\
\hline & NHS & GNJ & IG & IGxNHS & IGxGNJ & Male & Female & G & GD & GxGD & \\
\hline \multicolumn{12}{|c|}{ Breast } \\
\hline Moisture (\%) & 74.27 & 74.33 & 75.62 & 76.51 & 74.11 & 74.69 & 75.25 & 0.524 & 0.592 & 0.178 & 4.93 \\
\hline Protein $(\%)$ & 19.34 & 21.80 & 22.41 & 23.76 & 20.27 & 21.19 & 21.74 & 0.068 & 0.660 & 0.114 & 16.68 \\
\hline EE $(\%)$ & $0.74 \mathrm{~B}$ & $0.73 \mathrm{~B}$ & $0.47 \mathrm{~B}$ & $1.21 \mathrm{~A}$ & $1.38 \mathrm{~A}$ & $0.80 \mathrm{~b}$ & $1.03 \mathrm{a}$ & 0.001 & 0.030 & 0.150 & 40.17 \\
\hline ASH $(\%)$ & 1.26 & 1.34 & 1.25 & 1.91 & 1.28 & 1.22 & 1.31 & 0.385 & 0.054 & 0.094 & 13.04 \\
\hline \multicolumn{12}{|c|}{ Thigh } \\
\hline Moisture (\%) & $76.25 \mathrm{~B}$ & $76.31 \mathrm{~B}$ & $78.67 \mathrm{~A}$ & $75.92 \mathrm{~B}$ & $75.75 \mathrm{~B}$ & $77.03 a$ & $76.13 b$ & 0.001 & 0.026 & 0.002 & 1.79 \\
\hline Protein $(\%)$ & 17.35 & 20.16 & 19.33 & 19.93 & 19.93 & 18.96 & 19.73 & 0.389 & 0.442 & 0.221 & 18.35 \\
\hline EE $(\%)$ & $2.54 \mathrm{ABC}$ & $2.40 \mathrm{BC}$ & $1.69 \mathrm{C}$ & $2.88 \mathrm{AB}$ & $3.56 \mathrm{~A}$ & 2.58 & 2.65 & 0.001 & 0.773 & 0.952 & 33.38 \\
\hline ASH (\%) & 1.03 & 0.99 & 1.92 & 1.06 & 1.05 & $1.02 \mathrm{~b}$ & $1.11 \mathrm{a}$ & 0.082 & 0.047 & 0.870 & 14.80 \\
\hline
\end{tabular}

${ }^{1}$ Tukey test $(\alpha=0.05) ;{ }^{2}$ Coefficient of variation; namely: NHS - New Hampshire; GNJ - Gigante Negra de Jersey; RIR - Rhode Island Red; IG - Índio Gigante; IG x NHS - F1 generation of the crossing between birds of the Índio Gigante and New Hampshire breeds; IG x GNJ - F1 generation of the crossing between birds of the Indio Gigante and Gigante Negra de Jersey breeds; EE - ether extract; means followed by small letters (ab) denote difference between gender; means followed by capital letters $(\mathrm{AB})$ indicate difference among genotypes.

The bids of the IG $x$ NHS and IG x GNJ genetic groups presented higher means $(\mathrm{P}<0.01)$ of ether extract (EE) in the breast and thigh (Table 3), indicating that the crossing of the IG birds and the NHS and GNJ breeds provided the obtaining of offspring with higher amount of intramuscular fat, which can be associated to the effect of hybrid vigor and fattening ability. Faria et al. (2009); Mikulski et al. (2011); Sirri et al. (2011); Sarica et al. (2014) found highest means of EE for fat-growing strains, which was related to the greatest precocity of those birds when compared with the slow-growing ones.

In the breast, the only influence found was for gender $(\mathrm{P}<0.05)$ over ether extract $(\mathrm{EE})$, females showing the highest mean (Table 3). Similar results were found by Faria et al. (2009); Rizzi et al. (2009); Souza et al. (2011) who found highest means of EE of the breast for the females of different strains of free-ranging type chickens. Since females reached sexual maturity earlier, these tend to start the fat deposition in the carcass in earlier manner (Rizzi et al., 2009).

There was no effect of the genetic groups and gender $(\mathrm{P}>0.05)$ for the contents of moisture, protein and ash (Table 3) of the breast. Similar results were found by Sirri et al. (2011) who found no differences in the contents of moisture and protein of the breast among the strains of different growth potentials. For thigh, no effect of genotype and gender was found either $(\mathrm{P}>0.05)$. For thigh, no effect of genotype and gender over the values of thigh protein was found; either (Table 3) which stands out that the protein deposition in the thigh muscle was similar among the genetic groups in spite of the differences in relation to the other centesimal components. Those results agree with those of Faria et al. (2009) who also found no differences in the contents of the thigh protein among strains of different growth rates and gender.

For ash contents, while in the breast there was no influence of the factors studied $(\mathrm{P}>0.05)$; in the thigh, only differences between genders were found $(\mathrm{P}<0.05)$ with highest means being found for the females (Table 3 ). This parameter is an indicative of higher mineral content in the meat (Prandal et al., 1994) and similar behavior was found by Faria et al. (2009) who also found higher ash content for females regardless of the growth potential for birds slaughtered at 95 days.

For the thigh meat of the chicken of the different genetic groups and gender, interaction $(\mathrm{P}<0.05)$ between these factors for the physicochemical parameters, final $\mathrm{pH}$ and Luminosity (L*) (Table 2) was found and also for the moisture contents in the centesimal composition (Table 3). For the final $\mathrm{pH}$ of the thigh, there was difference $(\mathrm{P}<0.05)$ between genders, only for the GNJ genotype, the males presenting the highest mean. Among the males, the GNJ genotype showed the highest mean $(\mathrm{P}<0.001)$, being, however, similar to the IG and, among the females, the NHS genotype showed the highest mean $(\mathrm{P}<0.001)$, but similar to the means obtained by the GNJ e IG (Table 4). In general, the birds with different genetic characteristics tend to present variation in relation to the means of final $\mathrm{pH}$ and those with 
highest growth potential demonstrate lower values of that parameter (Faria et al., 2009), that behavior being related to the greatest predominance of glycolytic fibers where at post mortem occurs an increased production of lactic acid (Gomide et al., 2013).

Table 4. Slicing of the means of $\mathrm{pH}, \mathrm{L}^{*}$ and moisture content of the thigh meat of broilers bred in alternative system according to the interaction between genotypes and genders

\begin{tabular}{cccccccc}
\hline \multirow{2}{*}{ Variables } & \multirow{2}{*}{ Gender } & \multicolumn{9}{c}{ Genotype } & \multicolumn{2}{c}{ P value $^{1}$} \\
\cline { 3 - 7 } & & NHS & GNJ & IG & IGxNHS & IGxGNJ & Genotype \\
\hline \multirow{2}{*}{$\mathrm{pH}$} & MALE & $6.23 \mathrm{aBC}$ & $6.42 \mathrm{aA}$ & $60.29 \mathrm{aAB}$ & $6.10 \mathrm{aCD}$ & $6.04 \mathrm{aD}$ & 0.001 \\
P value $^{1}$ & FEMALE & $6.35 \mathrm{aA}$ & $6.30 \mathrm{bAB}$ & $6.29 \mathrm{aAB}$ & $6.17 \mathrm{aB}$ & $5.98 \mathrm{aC}$ & 0.001 \\
& Gender & 0.052 & 0.049 & 0.868 & 0.191 & 0.374 & - \\
$\mathrm{L}^{*}$ & Male & $49.46 \mathrm{aA}$ & $49.67 \mathrm{aA}$ & $48.41 \mathrm{aA}$ & $47.10 \mathrm{bA}$ & $47.96 \mathrm{aA}$ & 0.241 \\
& Female & $48.71 \mathrm{aA}$ & $49.12 \mathrm{aA}$ & $47.41 \mathrm{aA}$ & $50.83 \mathrm{aA}$ & $50.10 \mathrm{aA}$ & 0.088 \\
P value $^{1}$ & Gender & 0.560 & 0.663 & 0.431 & 0.005 & 0.096 & - \\
MOISTURE & MALE & $75.85 \mathrm{aC}$ & $78.34 \mathrm{aAB}$ & $78.85 \mathrm{aA}$ & $75.81 \mathrm{aC}$ & $76.27 \mathrm{aBC}$ & 0.001 \\
(\%) $^{1}$ & FEMALE & $76.64 \mathrm{aAB}$ & $74.26 \mathrm{bB}$ & $78.49 \mathrm{aA}$ & $76.02 \mathrm{aAB}$ & $75.22 \mathrm{aB}$ & 0.001 \\
value $^{1}$ & Gender & 0.368 & 0.001 & 0.684 & 0.802 & 0.233 & - \\
\hline
\end{tabular}

${ }^{1}$ Tukey test $(\alpha=0.05)$; namely: NHS - New Hampshire; GNJ - Gigante Negra de Jersey; RIR - Rhode Island Red; IG - Índio Gigante; IG x NHS - F1 generation of the crossing between birds of the Índio Gigante and New Hampshire breeds; IG x GNJ F1 generation of the crossing between birds of the Índio Gigante and Gigante Negra de Jersey breeds; means followed by small letters $(\mathrm{ab})$ denote difference between gender; means followed by capital letters $(\mathrm{AB})$ indicate difference among genotypes.

For Luminosity $\left(\mathrm{L}^{*}\right)$ of the thigh meat, there was difference $(\mathrm{P}<0.01)$ due to gender only for the IG $x$ NHS genotype, with highest values for the females (Table 4). Souza et al. (2012); Sarica et al. (2014) found higher values of $\mathrm{L}^{*}$ of the thigh with lowest growth potential and ascribed that behavior to the variations in the values of final $\mathrm{pH}$, since they are correlated (Gomide et al., 2013).

There was difference $(\mathrm{P}<0.01)$ in the values of moisture of the thigh between the genders for the GNJ birds, the males presenting the highest value. With relation to the genetic groups, the IG birds of both genders showed greatest value $(\mathrm{P}<0.01)$ of thigh moisture; among the males, the IG birds presented mean similar to the GNJ and among the females, that similarity was with the NHS and IG $x$ NHS animals (Table 4). The reason why these genotypes present higher means of moisture is likely due to the lower mean of ether extract (EE) found, since the fat content in the meat is inversely proportional to the moisture content (Mikulski et al., 2011).

\section{CONCLUSIONS}

The purebred Índio Gigante birds presented the meat quality characteristics most desirable by the consumer relative to the physicochemical and centesimal composition parameters with meats with firmer texture and lower amount of fat. Its crossing with birds of the New Hampshire and Gigante Negra de Jersey breeds provided offspring with better chicken meat characteristics with the breast cut presenting a yellower coloration in addition to reduced final $\mathrm{pH}$ values in both cuts. Gender promoted small alterations in the centesimal composition of the breast and thigh without altering the meat quality aspects relative to the physicochemical parameters of both cuts.

\section{REFERENCES}

ALBINO, L.F.T. Criação de frango e galinha caipira sistema alternativo de criação de aves. In: ALBINO, L.F.T. (Ed.). Aves mais indicadas. [s.1.]: Aprenda Fácil, 2014. p.17-29.

ALVES, D.D.; GOES, R.H.T.B.; MANCIO, A.B. Maciez da carne bovina. Cienc. Anim. Bras., v.6, p.135-149, 2005.

ASSOCIAÇÃO Brasileira dos Criadores de Índio Gigante, 2016. Disponível em: $<$ http://abcig.com.br/>. Acessado em: $07 \mathrm{dez}$. 2016.

BRASIL. Ministério da Agricultura Pecuária e Abastecimento. Ofício Circular DOI/DIPOA $n^{\circ}$ 7, de 19 de maio de 1999. Normatização e comercialização do frango Caipira ou frango Colonial, também denominado "Frango Tipo ou Estilo Caipira" ou "Tipo ou Estilo Colonial". Diário Oficial da União, Brasília, 1999. 
CASTELLINI, C.; MUGNAI, C.; DAL BOSCO, A. Effect of organic production system on broiler carcass and meat quality. Meat Sci., v.60, p.219225, 2002.

COELHO, A.A.D.; SAVINO, V.J.M.; ROSÁRIO, M.F. et al. Características da carcaça e da carne de genótipos de frangos caipiras. Braz. J. Food Technol., v.10, p.9-15, 2007.

FANATICO, A.C.; PILLI, P.B.; EMMERT, J.L. et al. Meat quality of slow- and fast-growing chicken genotypes fed low-nutrient or standard diets and raised indoors or with outdoor access. Poult. Sci., v.86, p.2245-2255, 2007.

FARIA, P.B.; BRESSAN, M.C.; SOUZA, X.R. et al. Composição proximal e qualidade da carne de frangos das linhagens Paraíso Pedrês e Pescoço Pelado. Rev. Bras. Zootec., v.38, p.2455-2464, 2009.

FRONNING， G.W.; UIJTTENBOOGAART, T.G. Effect of post mortem electrical stimulation on color, texture, $\mathrm{pH}$ and cooking loses of hot and cold deboned chicken broiler breast meat. Poult. Sci., v.67, p.1536-1544, 1988.

GOMIDE, L.A.M.; RAMOS, E.M.; FONTES, P.R. (Ed.). Ciência e qualidade da carne fundamentos. Viçosa: UFV, 2013. 197p.

GORDON, S.H.; CHARLES, D.R. (Ed.). Niche and organic chicken products. Nottingham: Nottingham University Press, 2002. 76p.

GRASHORN, M.A. Fattening performance, carcass and meat quality of slow and fast growing broiler strains under intensive and extensive feeding conditions. Arch. Geflügelkd, v.76, p.173-181, 2006.

MIKULSKI, D.; CELEJ, J.; JANKOWSKI, J. et al. Growth performance, carcass traits and meat quality of slower-growing and fast-growing chickens raised with and without outdoor access. Asian-Austral. J. Anim. Sci., v.24, p.1407-1416, 2011.

OFFICIAL methods of analysis. 14.ed. Campinas: AOAC, 2005. 423p.
PRANDAL, O.; BEKHIT, A.D.; BICKERSTAFFE, R. et al. (Eds.). Tecnología e hygiene de la carne. Zaragoza: ACRIBIA, 1994. $854 \mathrm{p}$.

RAMOS, E.M.; GOMIDE, L.A.M. (Eds.). Avaliação da qualidade de carnes: fundamentos e metodologias. Viçosa: UFV, 2007. 599p.

RIZZI, C.; BARUCHELO, M.; CHIERICATO, G.M. Slaughter performance and meat quality of three Italian chicken breeds. Ital. J. Anim. Sci., v.8, p.228-230, 2009.

SARICA, M.; YAMAK, U.S.; TURHAN, S. et al. Comparing slow-growing chickens produced by two- and three-way crossings with commercial genotypes. 2. Carcass quality and blood parameters. Eur. Poult. Sci., v.14, p.2014-20130, 2014.

SARSENBEK, A.; WANG, T.; ZHAO, J.K. et al. Comparison of carcass yields and meat quality between Baicheng-You chickens and Arbor Acres broilers. Poult. Sci., v.92, p.27762782, 2013.

SIRRI, F.; CASTELLINI, C.; BIANCHI, M. et al. Effect of fast, medium and slow-growing strains on meat quality of chickens reared under the organic farming method. Animal, v.5, p.312319, 2011.

SOUZA, X.R.; FARIA, P.B.; BRESSAN, M.C. Proximate composition and meat quality of broilers reared under different production systems. Rev. Bras. Cienc. Avic., v.13, p.15-20, 2011.

SOUZA, X.R.; FARIA, P.B.; BRESSAN, M.C. Qualidade da carne de frangos caipiras abatidos em diferentes idades. Arq. Bras. Med. Vet. Zootec., v.64, p.479-487, 2012.

ZANUSSO, J.T.; DIONELLO, N.J.L. Produção avícola alternativa: análise dos fatores qualitativos da carne de frangos de corte tipo caipira. Rev. Bras. Agrocienc., v.9, p.191-194, 2003. 